\title{
ЧАСТОТА ВИЯВЛЕННЯ БЕЗСИМПТОМНОГО ЗАСТОЮ ЖОВЧІ В ЗАЛЕЖНОСТІ ВІД ЛОКАЛІЗАЦЇ̈ ПЕРЕГИНІВ ЖОВЧНОГО МІХУРА ЗА ДАНИМИ УЛЬТРАСОНОГРАФІї
}

\author{
Заочний аспірант Зубко Л. Ю. \\ Україна, м. Львів, Львівський наиіональний медичний університет імені Данила Галицького, \\ кафедра оперативної хірургії з топографічною анатомією.
}

DOI: https://doi.org/10.31435/rsglobal_ws/30112019/6773

\section{ARTICLE INFO}

Received: 20 September 2019

Accepted: 11 November 2019

Published: 30 November 2019

\section{KEYWORDS}

Gallbladder,

excesses,

stagnation of bile,

adulthood,

ultrasound examination.

\begin{abstract}
In addition to diseases, the examination of the gallbladder and extrahepatic biliary tract reveal functional changes (excesses of the gallbladder, stagnation of bile) and individual anatomical features that do not affect the functioning of the system as a whole, do not cause painful sensations, but in unfavorable conditions lead to the development of diseases (formation of gallbladder stones, mechanical obstacles and acute inflammatory processes). In the course of our research, we determined the frequency of occurrence of asymptomatic bile stagnation, depending on the localization of excesses of the gallbladder in adults without pathology of the hepatobiliary system. The protocols of ultrasound examination of adults with pathology of the hepatobiliary system, performed with the ultrasound machine RadmirUltimaPU, were analyzed. In the first age group, combination of gallbladder excess and bile stagnation was found in 7.1\% (both men and women) of all surveyed. In the second age group, this indicator was $50 \%$ for men and $35.7 \%$ for women. Excesses of the gallbladder is more common in males $-21.6 \%$, in women $-15 \%$. Their frequency increases with age. The timely detection of functional features of the gallbladder in combination with the application of preventive recommendations can prevent the development of the disease.
\end{abstract}

Citation: Zubko L. Yu. (2019) Chastota Vyiavlennia Bezsymptomnoho Zastoiu Zhovchi v Zalezhnosti vid Lokalizatsii Perehyniv Zhovchnoho Mikhura za Danymy Ultrasonohrafii. World Science. 11(51), Vol.2. doi: 10.31435/rsglobal_ws/30112019/6773

Copyright: (C) 2019 Zubko L. Yu. This is an open-access article distributed under the terms of the Creative Commons Attribution License (CC BY). The use, distribution or reproduction in other forums is permitted, provided the original author(s) or licensor are credited and that the original publication in this journal is cited, in accordance with accepted academic practice. No use, distribution or reproduction is permitted which does not comply with these terms.

Вступ. Гепатобіліарна система постійно піддається впливу екзо- та ендогенних чинників. Виконує важливу роль в процесах забезпечення і підтримання життєдіяльності організму і його постійній адаптації. Основна увага сучасних досліджень спрямована на вдосконалення методик діагностики та лікування захворювань жовчного міхура та позапечінкових жовчних шляхів, що обумовлено соціально - економічним навантаженням [6, 3].

Окрім захворювань, при обстеженні жовчного міхура та позапечінкових жовчних шляхів виявляють функціональні зміни (перегини, застій жовчі) та індивідуальні анатомічні особливості, які не впливають на роботу системи вцілому, не викликають хворобливих відчуттів, але при несприятливих умовах ведуть до розвитку хвороби (утворення каменів, механічних перешкод та гострих запальних процесів). Пацієнти з безсимптомним застоєм жовчі мають щорічний ризик ускладнення гострим холециститом $0,3 \%$. Пусковим механізмом може стати зниження імунітету, вік, порушення моторики, токсичні впливи, інфекційні агенти $[1,2,7]$.

Вчасне виявлення ймовірних факторів ризику є передумовою для розробки комплексу індивідуальних профілактичних заходів та скринінгу з метою попередження хвороби. Жовчний міхур та позапечінкові жовчні шляхи візуалізуються за допомогою ультрасонографічного 
методу дослідження, що є атравматичним, доступним та малозатратним в порівнянні 3 іншими променевими методами дослідження. Чутливість методу $84,8 \%$, специфічність $85,1 \%[4,5,8]$.

Мета дослідження. Визначити частоту зустрічання безсимптомного застою жовчі в залежності від локалізації перегинів жовчного міхура у осіб зрілого віку без патології гепатобіліарної системи.

Матеріал і методи. Проведено аналіз протоколів ультразвукового обстеження осіб зрілого віку без патології гепатобіліарної системи. Обстеження проводили за допомогою ультразвукового апарату RadmirUltimaPU. До складу робочої групи було внесено протоколи обстеження 77 осіб (37 чоловіків та 40 жінок) у віці 21 - 60 років, ультрасонограми яких опрацьовували в подальшому.

До першої вікової групи увійшло 27 осіб (17 жінок (21 - 35 років) та 10 чоловіків (22 35 років)); до другої - 50 осіб (23 жінки (36 - 55 років) та 27 чоловіків (36 - 60 років).

\section{Результати дослідження.}

При відсутності у оглянутих пацієнтів скарг на розлади зі сторони гепатобіліарної системи, в процесі обстеження нами було виявлено морфологічні особливості (перегини) та функціональні порушення (застій жовчі) в обстежуваних структурах.

Особливості будови жовчного міхура у вигляді перегинів різної локалізації було виявлено у 14 осіб (18,1\%), з них 8 осіб чоловічої статі, та 6 осіб жіночої статі. Перегини локалізувались у наступних ділянках: перегин в ділянці шийки у 7 осіб (50\%); перегин в ділянці тіла - 2 (14,3\%); перегин в ділянці дна - 3 (21,4\%); перегин в ділянці тіла і шийки - 2 (14,3\%).

При аналізі частоти зустрічання перегинів у осіб різної статі виявлено, що серед оглянутих 37 чоловіків у 8 осіб (21,6\%) були перегини наступної локалізації: перегин в ділянці шийки у 3 осіб $(8,1 \%)$, перегин в ділянці тіла - 1 особа $(2,7 \%)$, перегин в ділянці дна - 2 особи $(5,4 \%)$, перегин в ділянці тіла і шийки - 2 особи (5,4\%). При обстеженні осіб жіночої статі ( 40 жінок), перегини виявлено у 6 осіб (15\%). Їх локалізація була наступна: перегин в ділянці шийки у 4 осіб (10\%), перегин в ділянці тіла - 1 особа (2,5\%),перегин в ділянці дна - 1особа (2,5\%), (рис. 1.).

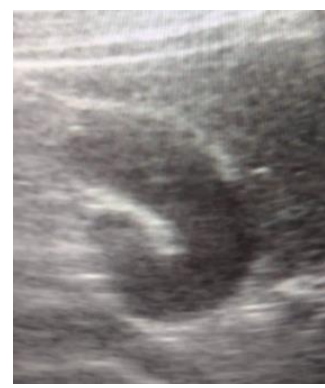

a)

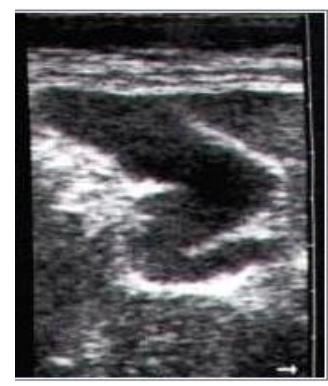

б)

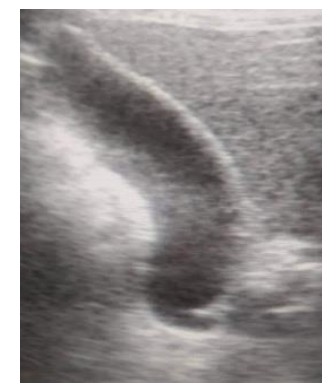

в)

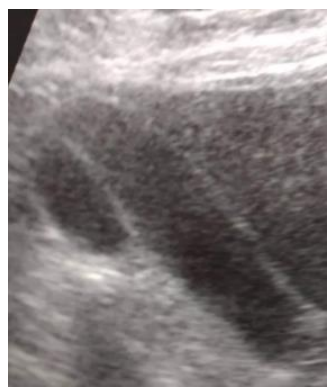

2)

Рис. 1. а) Сонограма жовчного міхура з локалізаџією перегину в діляниі тіла (чоловік 37 років).

б) Сонограма жовчного міхура з комбінованим перегином в діляниі шийки та тіла (чоловік 42 років). в) Сонограма жовчного міхура з локалізаџією перегину в ділянці шийки (жінка 47 років).

2) Сонограма жовчного міхура з локалізацією перегину в ділянці дна (жінка 52 роки).

У осіб першої вікової групи поєднання перегину жовчного міхура та застою жовчі виявлено у 7,1\% (як в чоловіків так і у жінок) від усіх обстежених. У осіб другої вікової групи даний показник становив у чоловіків $-50 \%$, у жінок $-35,7 \%$ (рис. 2.).

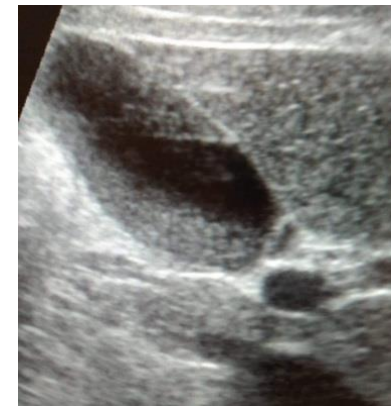

a)

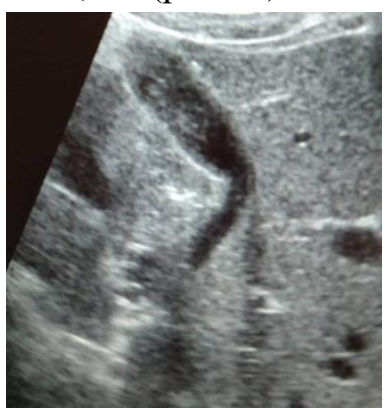

б)

Рис. 2. а, б) Візуалізація безсимптомного застою жовчі методом ультрасонографії у чоловіка 38 років та у жінки 26 років. 
Результати аналізу зіставлення виявленого застою жовчі та локалізації перегинів жовчного міхура у осіб різної статі зрілого віку подано у таблиці 1.

Таблиця 1. Локалізація перегинів жовчного міхура у осіб різної статі зрілого віку та частота виявлення застою жовчі.

\begin{tabular}{|l|l|l|l|l|l|l|l|l|}
\hline \multirow{2}{*}{\begin{tabular}{l} 
Локалізація \\
\cline { 2 - 9 }
\end{tabular}} & \multicolumn{3}{|c|}{ чоловіки } & \multicolumn{3}{c|}{ жінки } \\
\cline { 2 - 9 } & До 36р. & $\begin{array}{l}\text { Застій } \\
\text { жовчі,\% }\end{array}$ & Абс. & $\begin{array}{l}\text { 3астій } \\
\text { жовчі, } \%\end{array}$ & Абс. & $\begin{array}{l}\text { 3астій } \\
\text { жовчі, } \%\end{array}$ & Абс. & $\begin{array}{l}\text { 3астій } \\
\text { жовчі, } \%\end{array}$ \\
\hline $\begin{array}{l}\text { Перегин на рівні } \\
\text { шийки }\end{array}$ & 1 & 12,5 & 2 & 25 & 1 & 16,7 & 3 & 33,3 \\
\hline $\begin{array}{l}\text { Перегин на рівні } \\
\text { тіла }\end{array}$ & - & - & 1 & 12,5 & - & - & 1 & 16,7 \\
\hline $\begin{array}{l}\text { перегин на рівні } \\
\text { дна }\end{array}$ & - & - & 2 & 25 & - & - & 1 & 16,7 \\
\hline $\begin{array}{l}\text { Перегин на рівні } \\
\text { тіла і шийки }\end{array}$ & - & - & 2 & 12,5 & - & - & - & - \\
\hline
\end{tabular}

Перегини жовчного міхура як і застій жовчі частіше виявляються у чоловіків та жінок другої вікової групи. Серед осіб чоловічої статі структурні зміни у вигляді перегинів жовчного міхура зустрічаються частіше у другій віковій групі. Безсимптомний застій жовчі виявляється частіше при локалізації перегину на рівні шийки та на рівні дна жовчного міхура і становить $25 \%$. Серед осіб жіночої статі у другій віковій групі застій жовчі найчастіше виявляється при локалізації перегину на рівні шийки $33,3 \%$, при локалізації перегину на рівні тіла та дна застій жовчі становить 16,7\%, комбінованого перегину жовчного міхура у осіб жіночої статі, які ввійшли до робочої групи не виявлено (рис. 3).

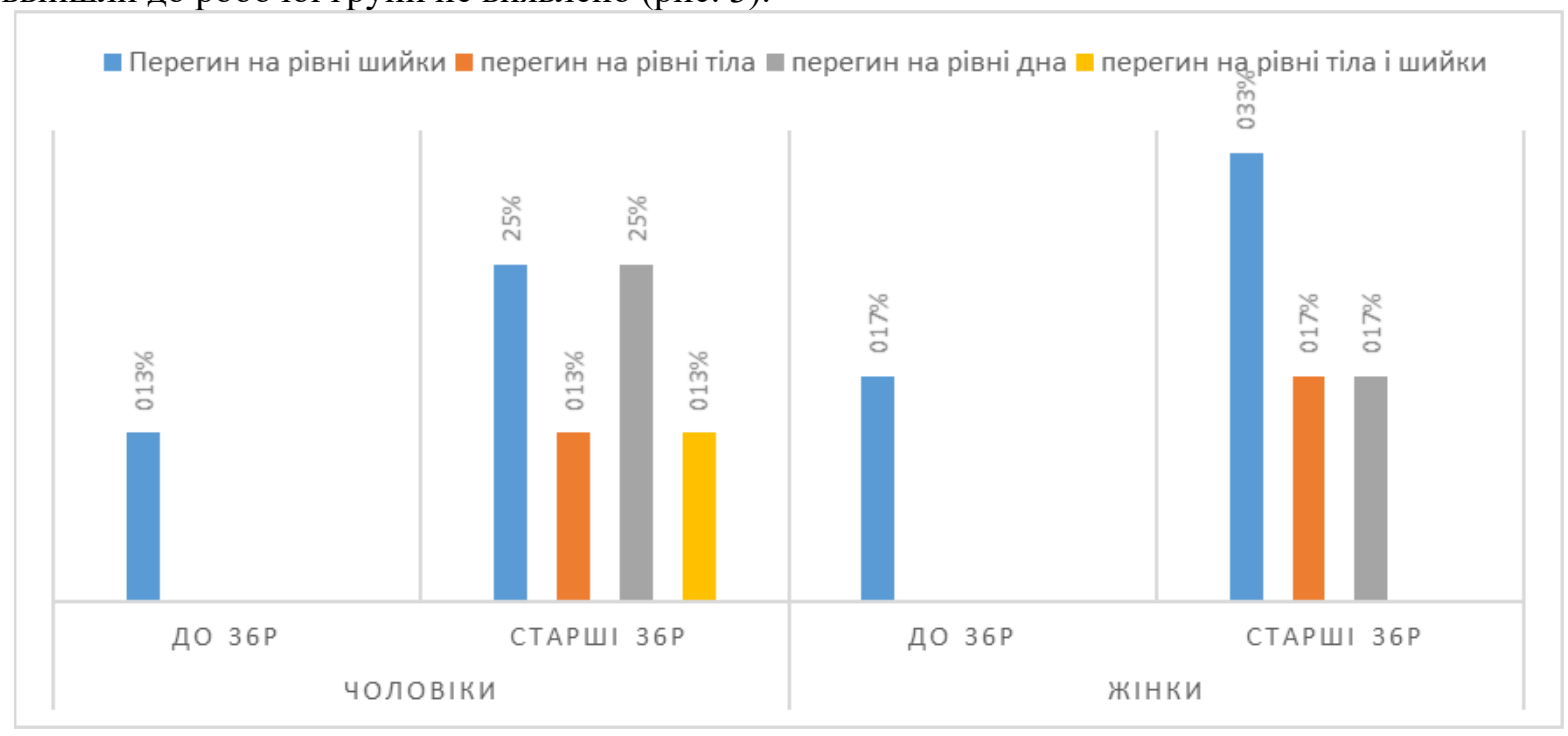

Рис. 3. Частота виявлення безсимптомного застою жовчі у осіб різної статі в залежності від локалізації перегинів жовчного міхура.

\section{Висновки:}

1. Перегини жовчного міхура частіше виявляються у осіб чоловічої статі $-21,6 \%$, у жінок - 15\%. Їх частота збільшується з віком.

2. Безсимптомний застій жовчі у першій та другій віковій групі найчаспіше поєднується з локалізацією перегину на рівні шийки жовчного міхура у осіб обох статей.

3. У першій віковій групі застій жовчі виявлено у 16,7\% обстежених жінок, та 12,5\% обстежених чоловіків.

4. У другій віковій групі застій жовчі частіше виявляють у жінок. 33,3\% при перегині в ділянці шийки, та у 16,7\% випадків при перегині на рівні тіла та дна жовчного міхура.

Виявлення функціональних особливостей жовчного міхура у вигляді перегинів та безсимптомного застою жовчі є підставою для розпрацювання профілактичних рекомендацій, 
що в свою чергу може знизити ризик утворення жовчних каменів, запальних процесів жовчовивідних шляхів та зменшити потребу оперативних втручань.

\section{ЛІТЕРАТУРА}

1. Vasyliv M.A., Zubko L.Yu., Masna Z.Z., Sernyak V.R., Chervinska M.Y. Structural peculiarities of gallbladder in ultrasonographic and computer-tomographic images. XXVI International Symposium on Morphological Sciences. 2018: 81.

2. Zubko L.Yu., Masna Z.Z. Morphological peculiarities of the gallbladders structure and it's functional changes in healthy individuals of different sexes according to the findings of ultrasound examination. Deutscher Wissenschaftsherold German Science Herald. 2017;6: 80-83.

3. Лоранская ИД. Функциональные расстройства билиарного тракта. М.: Форте принт; 2013. 92c.

4. Скирда I.Ю., Гладун В.М., Закревська О.В. Точність методів візуалізації у діагностиці гострого холециститу. Гастроентерологія. 2015;1:31 - 41.

5. Стародуб Є.М., Самогальська О.Є., Шостак С.Є. Алгоритм діагностики та лікування хвороб органів травлення. Тернопіль; 2008. 196с.

6. Щербініна М.Б., Скирда І.Ю., Буренко А.М. Біліарна патологія: камінь спотикання на рівній дорозі сучасної гастроентерології. Здоров’я України. 2010;2:18-19.

7. Іжицька Н.В. Дискінезія жовчовивідних шляхів в практиці сімейного лікаря. Актуальні проблеми сучасної медицини. Вісник української медичної стоматологічної академії. 2015;4(52):314-319.

8. Сиволап В.Д. Ультразвукова діагностика патології гепатобіліарної системи. Запоріжжя:3ДМУ;2018. 81с. 